\title{
ELECTROCHEMICAL INCINERATION OF REFRACTORY ORGANIC POLLUTION BY ELECTROCHEMICALLY GENERATED FENTON'S REAGENT
}

\author{
AZRI YAMINA MOUNIA ${ }^{1^{*}}$ and ZEROUALI DJILALI ${ }^{2}$ \\ ${ }^{I}$ Department of chemistry, Faculty of Sciences, Laboratory of Electrochemical, University of Sciences and \\ Technology of Oran U.S.T.O. BP-1505 el M'naouer Oran 31000 -Algeria \\ ${ }^{2}$ Department of chemistry, Faculty of Sciences, Laboratory of Electrochemical, University of Sciences and \\ Technology of Oran U.S.T.O. BP -1505 el M'naouer Oran 31000 -Algeria
}

(Received: June 28, 2012 - Accepted: July 20, 2012)

\begin{abstract}
ABSTRAT
The electro-Fenton process is an electrochemical method for waste water treatment based on the production of hydroxyl radicals via $\mathrm{H}_{2} \mathrm{O}_{2}$ generation in the presence of ferrous ions. The aim of this work is of applied Electro-Fenton technique to incinerate lubricate additive biocide $\mathrm{N}, \mathrm{N}$-methylenebismorpholine $\left(\mathrm{C}_{9} \mathrm{H}_{18} \mathrm{~N}_{2} \mathrm{O}_{2}\right)$.the effect of some operational parameters such as applied cathodic potential, the electrolysis time and aeration,concentration of supporting electrolyte on the generation of $\mathrm{H}_{2} \mathrm{O}_{2}$ was investigated. The optimal cathodic potential on the generation of $\mathrm{H}_{2} \mathrm{O}_{2}$ production was $-500 \mathrm{mV} / \mathrm{SCE}$ corresponding to a density current of $1.4 \mathrm{~mA} / \mathrm{cm}^{2}$, the production of hydrogen peroxide with the aeration and electrolysis time, then became stationary after $2 \mathrm{~h}$ of electrolysis, the low $\mathrm{pH}$ favorite production of $\mathrm{H}_{2} \mathrm{O}_{2}$ electro generated. Whereas the

Concentrations of supporting electrolyte of the solution have a slight affect. The degradation and incineration of N,N-methylenebismorpholine in the optimized parameters was also investigated (potential, current density, $\mathrm{COD} / \mathrm{Fe}^{2+}$ ratio ) the result indicates that $97 \%$ of $\mathrm{COD}$ was incinerated at $50 \mathrm{~mA}$ and the optimal concentration of catalyst is between 28 and $58 \mathrm{mg} / \mathrm{l}$.
\end{abstract}

Keywords: indirect oxidation, Electro-Fenton, biocide, hydrogen peroxide, oxygen reduction

\section{INTRODUCTION}

Recently advanced oxidation process (AOP) have attracted more and more attention because they can be used to degrade pollutants in water by generating plenty of hydroxyl radical $(\mathrm{OH} \bullet)^{1,2}$.hydroxyl radicals $(\mathrm{OH} \bullet)$ are non selective, very powerful oxidants $\mathrm{E}_{\mathrm{OH} / \mathrm{OH}-}=+2.8 \mathrm{~V} / \mathrm{SHE}^{3}$ (standard hydrogen electrode) in acidic medium. They are able to react with organic pollutants to mineralize these pollutants into $\mathrm{CO}_{2}$, water and inorganic ions.

The production of radical hydroxide is generated by redox reaction of hydrogen peroxide and ferrous ions.

$$
\mathrm{H}_{2} \mathrm{O}_{2}+\mathrm{Fe}^{2+} \mathrm{\square} \mathrm{OH}^{\cdot}+\mathrm{Fe}^{3+}+\mathrm{OH}^{-}
$$

Reaction (1) is called "Fenton Reaction" and the process is called "Fenton process".

In traditional Fenton process, the reactants $\mathrm{H}_{2} \mathrm{O}_{2}$ and $\mathrm{Fe}^{2+}$ are simultaneously added to the polluted solution and it is employed to efficiently treat a variety of industrial pollution. ${ }^{4}$ Waste water containing a range of organic compounds like phenol, pesticides, plastic additives and rubber chemicals with low cost and relatively easy operation and maintenance 5,6 however despite its high efficiency the wide of application of traditional Fenton process is limited by its acidic $\mathrm{pH}$ requirement $(\mathrm{pH} 2-4)$ and the formation of ion sludge in the coagulation step as well as high cost of hydrogen peroxide.

In order to avoid the use of expensive hydrogen peroxide electro-Fenton process was established in this process hydroxyl radicals are produced via Fenton's reaction in homogeneous medium via electro-generated $\mathrm{H}_{2} \mathrm{O}_{2}$ and dissolved iron ions

According to Pourbaix diagrams, the oxidation/reduction of water and oxygen gives a possible electrochemical way to produce hydrogen peroxide using cathodic reduction of dissolved oxygen in aqueous medium ${ }^{7}$ Pourbaix .

$$
\mathrm{H}_{2} \mathrm{O}_{2}+2 \mathrm{H}^{+}+2 \mathrm{e}^{-} \rightarrow 2 \mathrm{H}_{2} \mathrm{O}
$$

The electro-reduction of dissolved oxygen is a multi-electron reaction associated with the formation of a large number of intermediates. Oxygen can be reduced directly to $\mathrm{H}_{2} \mathrm{O}$ in a 4-electron transfer:

$$
\mathrm{O}_{2}+4 \mathrm{H}^{+}+4 \mathrm{e}^{-} \rightarrow 2 \mathrm{H}_{2} \mathrm{O}
$$

Or, first reduced to $\mathrm{H}_{2} \mathrm{O}_{2}$ in a 2-electron transfer:

$$
\mathrm{O}_{2}+2 \mathrm{H}^{+}+2 \mathrm{e}^{-} \rightarrow \mathrm{H}_{2} \mathrm{O}_{2}
$$

This 2-electron transfer is then followed by reduction of $\mathrm{H}_{2} \mathrm{O}_{2}$ to $\mathrm{H}_{2} \mathrm{O}$

$$
\mathrm{H}_{2} \mathrm{O}_{2}+2 \mathrm{H}^{+}+2 \mathrm{e}^{-} \rightarrow 2 \mathrm{H}_{2} \mathrm{O}
$$

The reaction (4) can take place at different cathode such as mercury pool ${ }^{8}$, gold ${ }^{9}$ reticulate vitrous carbon ${ }^{10,11}$, activated carbon fiber ${ }^{12}$,carbon felt ${ }_{13,14,15}$ and $\mathrm{O}_{2}$-diffusion cathodes ${ }^{16,17,18}$.

The oxidative power of electrogenerated hydrogen peroxide is enhanced in the presence of $\mathrm{Fe}^{2+}$ ions ${ }^{8,17}$ to produce $\mathrm{OH} \bullet$ through a Fenton process (reaction $1)$.

The regeneration of $\mathrm{Fe}^{2+}$ can occur either direct cathodic reaction (reaction 6) by the oxidation of an organic (reaction 7) or by the reaction with $\mathrm{H}_{2} \mathrm{O}_{2}$ (reaction 8) ${ }^{19}$.

$$
\begin{aligned}
& \mathrm{Fe}^{3+}+\mathrm{e}^{-} \rightarrow \mathrm{Fe}^{2+} \\
& \mathrm{Fe}^{3+}+\mathrm{R} \cdot \rightarrow \mathrm{Fe}^{2+}+\mathrm{R}^{+} \\
& \mathrm{Fe}^{3+}+\mathrm{H}_{2} \mathrm{O}_{2} \rightarrow\left[\mathrm{Fe}-\mathrm{O}_{2} \mathrm{H}\right]^{2+}+\mathrm{H}^{+} \rightarrow \mathrm{HO}_{2}
\end{aligned}
$$

In general, all reductions in aqueous medium are perturbed by hydrogen evolution, which depends on hydrogen overpotential of the cathodic materials.

Mercury, lead and graphite exhibit large overpotentials for hydrogen evolution, however, mercury and lead are not compatible with the environment and their use in industrial application is not recommended. Actual research on adapted materials focused on Boron Doped Diamond (BDD) which provides a high $\mathrm{O}_{2}-$ overvoltage anode. In this case, hydroxyl radicals are formed in the medium from Fenton's reaction (reaction 1) ${ }^{20,21}$. However, industrial applications need electrodes with specific large surfaces, high availability and a minimum cost.

In this paper, we studied the performance of the graphite cathode for $\mathrm{H}_{2} \mathrm{O}_{2}$ electrogeneration, and investigated the degradation of $\mathrm{N}, \mathrm{N}$ Methylenebismorpholine in the Electro-Fenton process using the graphite cathode. The influence of the different operational parameters on the $\mathrm{H}_{2} \mathrm{O}_{2}$ electrogeneration (cathodic potential, time of aeration and electrolysis, concentration of supporting electrolyte) and the incineration and mineralization of $\mathrm{N}, \mathrm{N}$-methylenebismorpholine (ratio $\mathrm{COD} / \mathrm{Fe}^{2+}$, current) which affect the efficiency of electro-Fenton process in biocide oxidation in acidic solutions.

\section{EXPERIMENTAL}

\section{Reagent and material:}

The graphite electrode was supplied by Algerian Electrical and Gas Company. The surface of electrode was polished using 600 and $1600 \mathrm{SiC}$ papers. After polishing the electrode were rinsed, sonicated for $15 \mathrm{~min}$, and rinsed with deionized water.

The biocide N,N Methylenebismorpholine was supplied by Algerian 
petroleum refinery of Arzew the N,N Methylenebismorpholine is used as biocide to preserve lubricating oil from a biological oxidation. Thus, it is likely a non biodegradable and cannot be treated by conventional techniques. It is not compatible with biological process for the treatment of waste water issued from petrochemical industries. Therefore, it is necessary to incinerate this petrochemical pollutant before the biological treatment. The $\mathrm{N}, \mathrm{N}$ Methylenebismorpholine was used without further purification and its structure is shown in fig 1. All other chemicals including sulfuric acid $\mathrm{H}_{2} \mathrm{SO}_{4}$, sodium hydroxide $\mathrm{NaOH}$, anhydrous sodium sulfate $\mathrm{Na}_{2} \mathrm{SO}_{4}$, hydrogen tetrachlorate HAuClO $99 \%$; heptahydrate ferrous sulfate $\mathrm{FeSO}_{4} 7 \mathrm{H}_{2} \mathrm{O}$, anhydrous ferric sulfate $\mathrm{Fe}_{2}\left(\mathrm{SO}_{4}\right)_{3}$, sulfate titanium (IV) $\mathrm{Ti}\left(\mathrm{SO}_{4}\right)_{2}$, potassium dichromate $\mathrm{K}_{2} \mathrm{Cr}_{2} \mathrm{O}_{7}$ and ammonium iron(II) sulfate hexahydrate (Mohr salt) $\mathrm{Fe}\left(\mathrm{NH}_{4}\right)$ $\left(\mathrm{SO}_{4}\right)_{2} \cdot 6 \mathrm{H}_{2} \mathrm{O}$, silver sulfate $\mathrm{Ag}_{2} \mathrm{SO}_{4}$, sulfate mercury $\mathrm{HgSO}_{4}$ were of analytical grade, deionized water was used.

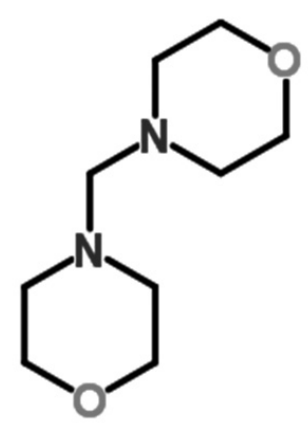

Figure1. Structure of N,N-Methylenebismorpholine.

Electrochemical device (figure 2):

Electrolyses were carried out in double compartment cells, POTENTIOSTAT TACUSSEL 40-1X was used in both potentiodynamic and potentiostatic experiments. The working electrode was industrial graphite with tubular form and an area of $36 \mathrm{~cm}^{2}$ (Figure 1).A saturated calomel electrode (SCE) was used as a reference electrode. The counter electrode was platinum grid of $2 \mathrm{~cm}^{2}$. Potentiodynamic curves were plotted using an X-T POTENTIOMETRIC LEYBOLD-HERAREUS ENREGISTRER.

The anodic compartment consists of a glass tube with a glass-frit bottom which allows its separation of the cathodic compartment. Anodic compartment was filled with a solution of $\mathrm{Na}_{2} \mathrm{SO}_{4} 0.5 \mathrm{M}$ as an electrolyte and the cathodic compartment was filled with an acidified solution of $\mathrm{H}_{2} \mathrm{SO}_{4}(\mathrm{pH} 3)$. Oxygen was bubbled through the cathodic compartment during the experiment with a flow rate of 1 liter/ min. The resulting oxygen concentration was measured by oxymeter (Model 97-08-99, Orion Research INC).

Experimental solutions were magnetically stirred.

Analytical procedures:

Hydrogen peroxide analysis:

Concentration of hydrogen peroxide produced in the cell was analyzed by titanic sulfate, $\mathrm{Ti}\left(\mathrm{SO}_{4}\right)_{2}$ method Eisenberg ${ }^{22}$. Spectrophotometer SAFAS $320 \mathrm{G}$ was used to measure the light absorbance of the $\mathrm{Ti}^{4+}-\mathrm{H}_{2} \mathrm{O}_{2}$ orange complex at $410 \mathrm{~nm}$.

Chemical oxygen demand (COD) analysis:

Chemical oxygen demand (COD) was measured according to French AFNOR norm. Samples withdrawn during electro Fenton processing were filtered through a Millex-GV Millipore hydrophilic membrane with $0.22 \mu \mathrm{m}$ pore diameter.

The organic matter was oxidized by potassium dichromate $\mathrm{K}_{2} \mathrm{Cr}_{2} \mathrm{O}_{7}$ in the presence of silver sulfate (catalyst) and mercury sulfate for $2 \mathrm{~h}$ at $170^{\circ} \mathrm{C}$. COD was calculated from the following equation:

$\operatorname{COD}\left(\mathrm{mg} \mathrm{O}_{2} 1^{-1}\right)=8000\left(\mathrm{~V}_{\text {MS blank }}-\mathrm{V}_{\text {MS sample }}\right) \times \mathrm{N}_{\mathrm{MS}} / \mathrm{V}_{0}$

Where $\mathrm{V}_{\text {SS bank }}$ and $\mathrm{V}_{\mathrm{MS}}$ sample are the volumes of standard Mohr salt solution using the blank and sample respectively, $\mathrm{N}_{\mathrm{MS}}$ is the normality of the Mohr salt, and $\mathrm{V}_{0}$ is the volume of the sample.
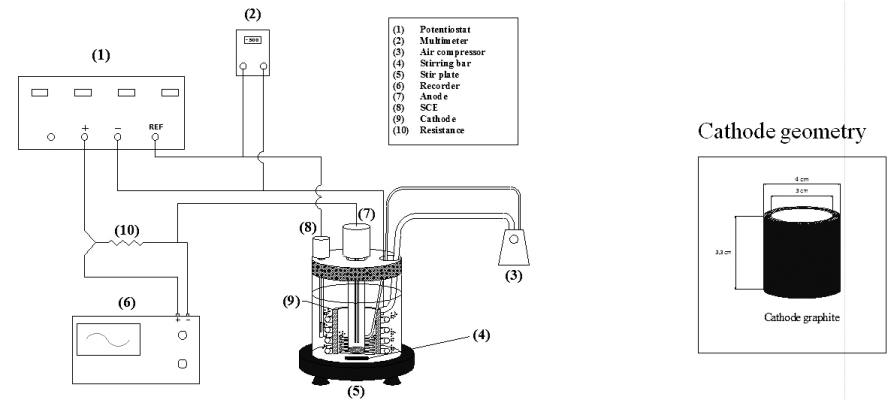

Figure 2. Experimental device for potentiodynamic test

\section{RESULTS AND DISCUSSION}

In this part of study, the factors significantly affecting the limiting current of $\mathrm{H}_{2} \mathrm{O}_{2}$ generation, including cathodic potential, time of electrolysis and aeration, $\mathrm{pH}$ and concentration of supporting electrolyte were investigated using potential mode, under this mode, the electrical current was monitored on line by digital multimeter.

\section{Optimal cathodic potential:}

A solution of $0.5 \mathrm{M} \mathrm{Na}_{2} \mathrm{SO}_{4}, \mathrm{pH} 3$ and saturated air (oxygen level $=7 \mathrm{mg} / \mathrm{l}$ ) were used for cathodic polarizations, air was bubbled during all experiment with a rate of 1 liter $/ \mathrm{mn}$. A range of potentials of $-100 \mathrm{mV} / \mathrm{SCE}$ to $-900 \mathrm{mV} /$ SCE were investigated with a scan rate of $2 \mathrm{mV} / \mathrm{s}$.

Polarization curve reflect current response with the cathodic potential applied I-E, the figure (3) shows that, two cathodic limiting current for oxygen and hydrogen peroxide reductions respectively according to reaction (2) and (3).

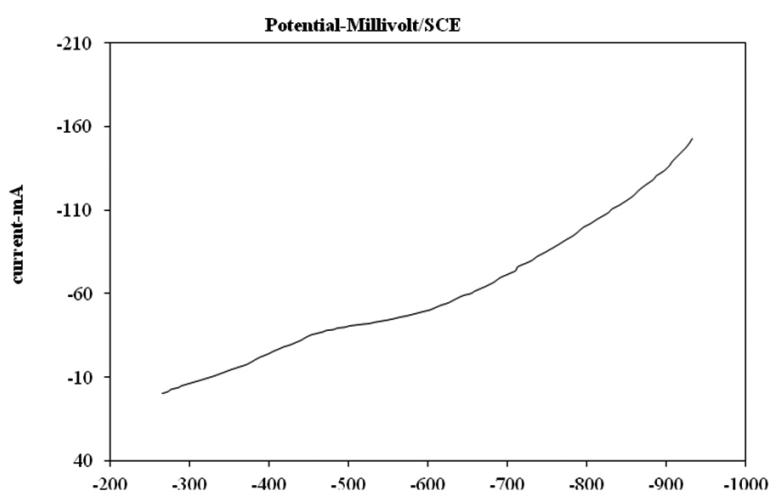

Figure 3.Potentiodynamic polarization of industrial graphite.

Experimental conditions: Scan rate $=2 \mathrm{mV} / \mathrm{s} ; \mathrm{pH}=3 ; \mathrm{C}_{\mathrm{O} 2}=7 \mathrm{mg} / \mathrm{l}$, Electrolyte $=0.5 \mathrm{M} \mathrm{Na}_{2} \mathrm{SO}_{4}$

The reduction of oxygen to give peroxide occurs in the potential range of $\mathrm{E}=-300 \mathrm{mV} / \mathrm{SCE}$ to $-500 \mathrm{mV} / \mathrm{SCE}$, and the hydrogen peroxide reduction in the range of $\quad-500 \mathrm{mV} / \mathrm{SCE}$ to $-650 \mathrm{mV} / \mathrm{SCE}$. For more negative values of potential, cathodic current increases strongly exhibiting hydrogen evolution (eq 9).

$$
2 \mathrm{H}^{+}+2 \mathrm{e}^{-} \rightarrow \mathrm{H}_{2}
$$

These results are in accordance with Qiang (2002) and Oturan and Pinson (1992). ${ }^{23,24}$ Potentials of $-600 \mathrm{mV} / \mathrm{SCE}$ was obtained by Chu (1995) and $-550 \mathrm{mV} / \mathrm{SCE}$ by Hsioa and Nobe $(1993)^{25,26}$. The use of industrial graphite gives a good concordance in the range of reduction potential of reduction of oxygen to hydrogen peroxide.

At the anode, the oxidation of $\mathrm{H}_{2} \mathrm{O}$ releases oxygen gas and protons

$$
2 \mathrm{H}_{2} \mathrm{O} \rightarrow 4 \mathrm{H}^{+}+\mathrm{O}_{2}+4 \mathrm{e}^{-}
$$

The protons so generated will be driven to the catholyte electro-statically and partially supplement the protons consumption during the synthesis of $\mathrm{H}_{2} \mathrm{O}_{2}$. 
Potentiostatic electro generation of hydrogen peroxide

Potensiostatic electro generation of hydrogen peroxide was performed in a two compartments cell. Effect of applied potentials, time of electrolysis and time of pre-aeration before the start of electrolysis were experimented for $\mathrm{Na}_{2} \mathrm{SO}_{4}(0.05 \mathrm{M})$ and $(\mathrm{pH} 3)$ solution was magnetically stirred. Hydrogen peroxide was analyzed every hour.

Effect of applied potential:

Figure 4 shows the effect of applied potential on hydrogen peroxide electro generation in the range of $-100 \mathrm{mV}$ to $-900 \mathrm{mV} / \mathrm{SCE}$. The curve represents a maxima in the potential range from $\mathrm{E}=-500$ to $\mathrm{E}=-550 \mathrm{mV} / \mathrm{SCE}$, corresponding to the limiting current as in Figure 3.

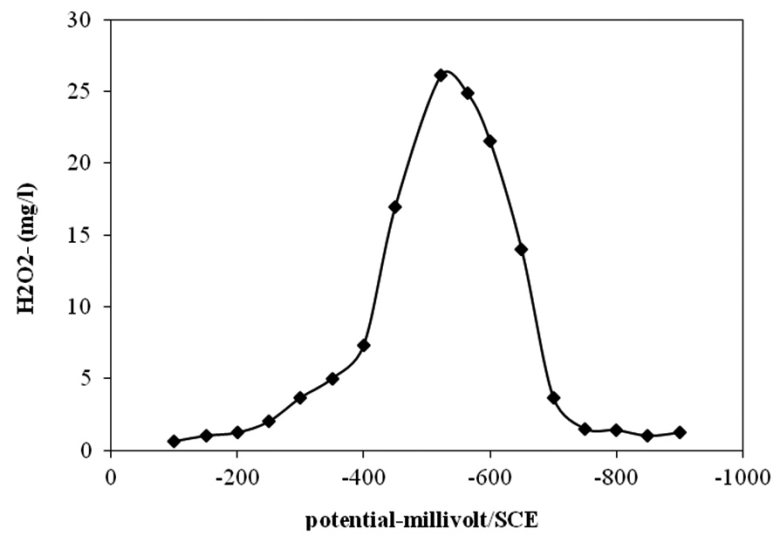

Figure 4. Effect of cathodic potential on Hydrogen Peroxide production Electrolyte: $\mathrm{Na}_{2} \mathrm{SO}_{4}(0.5 \mathrm{M}), \mathrm{p} \mathrm{H} 3$, time of electrolysis: $2 \mathrm{~h}$

A maximum rate of hydrogen peroxide $(26 \mathrm{mg} / \mathrm{l})$ was electrogenerated at a potential of $-500 \mathrm{mV} / \mathrm{SCE}$ after 2 hours of electrolysis. The best potential for oxygen to Hydrogen peroxide reduction $(-500 \mathrm{mV} / \mathrm{SCE})$ is in accordance with the theorist results of ${ }^{23,24,27}$ (Qiang et al 2002; Oturan et al 1992; Tzedakis et al 1989 ) and with the potentiodynamic results.

Effect of time of electrolysis and time of aeration:

Effect of aeration before and during the electrolysis on hydrogen peroxide production was experimented for a potential of $-500 \mathrm{mV} / \mathrm{SCE}$. A solution of $\mathrm{Na}_{2} \mathrm{SO}_{4}(0.5 \mathrm{M}) \mathrm{pH} 3$, magnetically stirred was used in the experiment.

The results of figure 5 showed two parts: a rapid increase of hydrogen peroxide production for times less than approximately $2 \mathrm{~h}$, then the production of hydrogen peroxide stabilizes.

The stabilized production of hydrogen peroxide is probably due to equilibrium between the production and decomposition of hydrogen peroxide .Pourbaix's $s^{7}$ diagram of hydrogen peroxide Pourbaix shows instability domains of hydrogen peroxide which can be oxidized to form oxygen or reduced to form $\mathrm{H}_{2} \mathrm{O}$. The plateau of Figure 5 indicates that the production and decomposition occur simultaneously after two hours of electrolysis. The decomposition becomes higher and the production increases slightly.

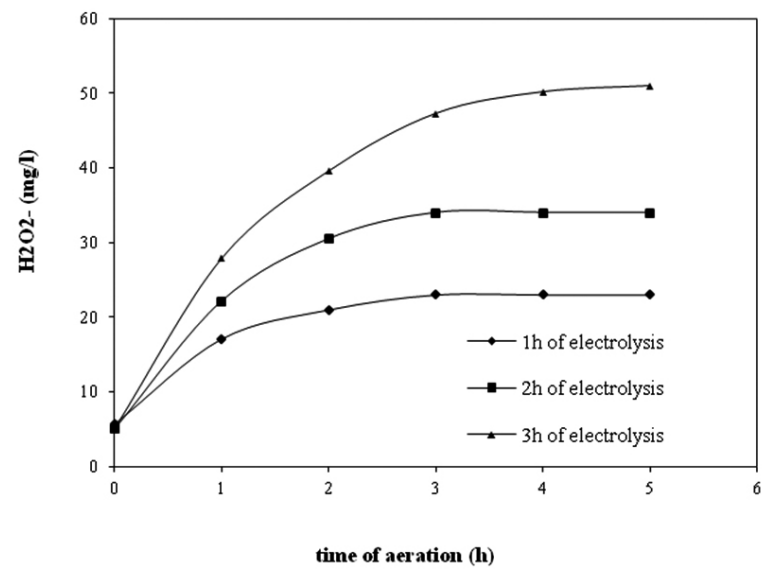

Figure 5. effect of time of aeration

\section{Effect of pH}

Electro-Fenton reaction is generally performed in acidic conditions $\mathrm{pH}$ values between 2 and 4 . The optimum $\mathrm{pH}$ value was 2.8 for hydroxyl radical production ${ }^{28}$, Ferric species begin to precipitate as ferric hydroxides at higher $\mathrm{pH}$ values. On the other hand, ferric species form stable complexes with $\mathrm{H}_{2} \mathrm{O}_{2}$ at lower $\mathrm{pH}$ values. Here, we only investigated the effect of $\mathrm{pH}$ on the electrogeneration of $\mathrm{H}_{2} \mathrm{O}_{2}$ using graphite cathode in a solution of $\mathrm{Na}_{2} \mathrm{SO}_{4}$ $0.5 \mathrm{M}$ in acidic region between the $\mathrm{pH}$ values of 1 to 4 by addition of $\mathrm{H}_{2} \mathrm{SO}_{4}$ or $\mathrm{NaOH}$ in the absence of ferric or ferrous ions, it can be seen from figure 6 . That there is a maximum value, of the $\mathrm{H}_{2} \mathrm{O}_{2}$ concentration is $\mathrm{pH} 3$ after $120 \mathrm{~min}$ of electrolysis. However below $\mathrm{pH} 2$ the maximum value of $\mathrm{H}_{2} \mathrm{O}_{2}$ concentration was of $16 \mathrm{mg} / 1$. this could be explained by the formation of oxonium ion $\left(\mathrm{H}_{3} \mathrm{O}_{2}^{+}\right)^{29,30}$, which enhanced the stability of $\mathrm{H}_{2} \mathrm{O}_{2}$ (eq 10). At same time, a low $\mathrm{pH}$ also promotes hydrogen evolution according to (eq 9), and then reduces the number of active sites for generating hydrogen peroxide ${ }^{31}$.

$$
\mathrm{H}_{2} \mathrm{O}_{2}+\mathrm{H}+\rightarrow \mathrm{H}_{3} \mathrm{O}_{2}^{+}
$$

Above $\mathrm{pH} 2$, the values of $\mathrm{H}_{2} \mathrm{O}_{2}$ concentration decreases due to insufficient protons.

This result indicates that $\mathrm{pH} 2$ is the optimal condition which is an agreement with ${ }^{23}$. A fig.6b show that $i$ stabilize quickly after the electrolysis is initiated. A steady-state condition is rapidly reached because a constant dissolved oxygen concentration is maintained in solution.

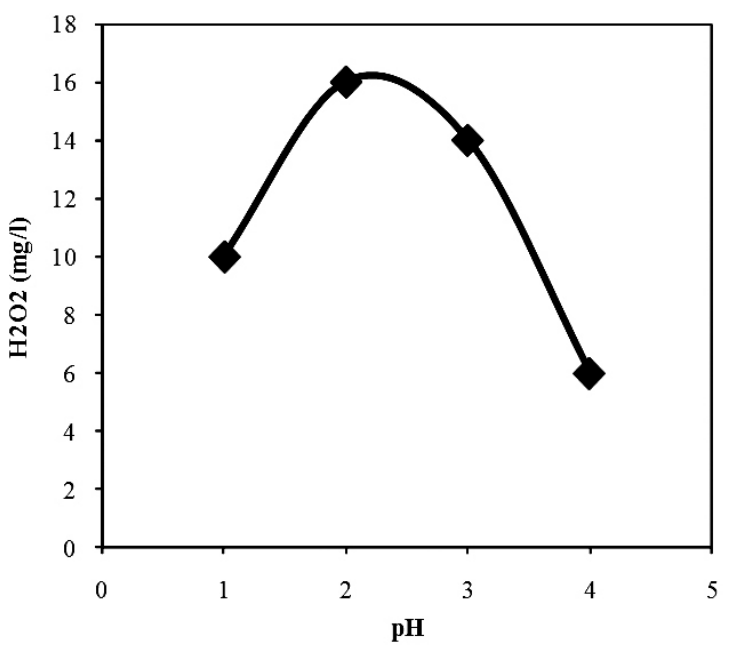

(a)

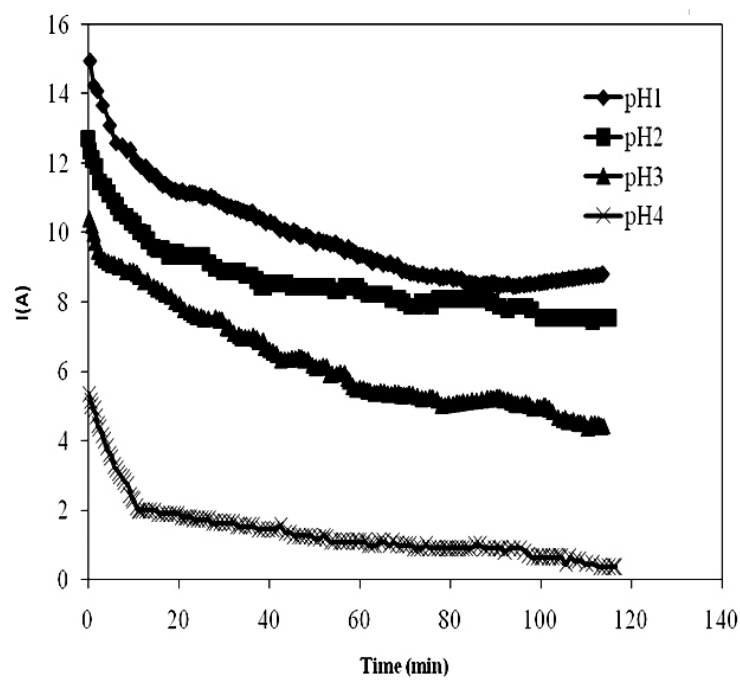

(b)

Figure6. Generation of $\mathrm{H}_{2} \mathrm{O}_{2}$ at various applied pH: (a) accumulated concentration; (b) current. Experimental conditions: time of aeration $1 \mathrm{H}$ time of electrolysis $120 \mathrm{~min}$ and $\mathrm{E}=-500 \mathrm{mV} / \mathrm{SCE}$ 
Effect of the concentration of support electrolyte

Electro-generation of $\mathrm{H}_{2} \mathrm{O}_{2}$ was examined in different concentration of supporting electrolyte $\left(0.05\right.$ to 0.9 mole/ $/ 1$ of $\left.\mathrm{Na}_{2} \mathrm{SO}_{4}\right)$ of $\mathrm{pH} 3$ and cathodic potential of $-500 \mathrm{mV} / \mathrm{SCE}$. From fig 7, it could be conclude that the electrogeneration of $\mathrm{H}_{2} \mathrm{O}_{2}$ is weakly affected by change in the concentration of supporting electrolyte whose role is to decrease the ohmic resistance of the solution and eliminate the migration current $\mathrm{Im}$, the overall current is $\mathrm{I}=\mathrm{Im}+\mathrm{Id}$. We believe that this current is eliminated by the highly acidic solution and transport phenomena in electrical mobility are much higher than that of sodium ions. However the addition of supporting electrolyte helps to improve the characteristics of conductive solution.

We chose a concentration 0.05 mole/ 1 for the rest of this part of study. This value has been used by several researchers ${ }^{32,33}$.

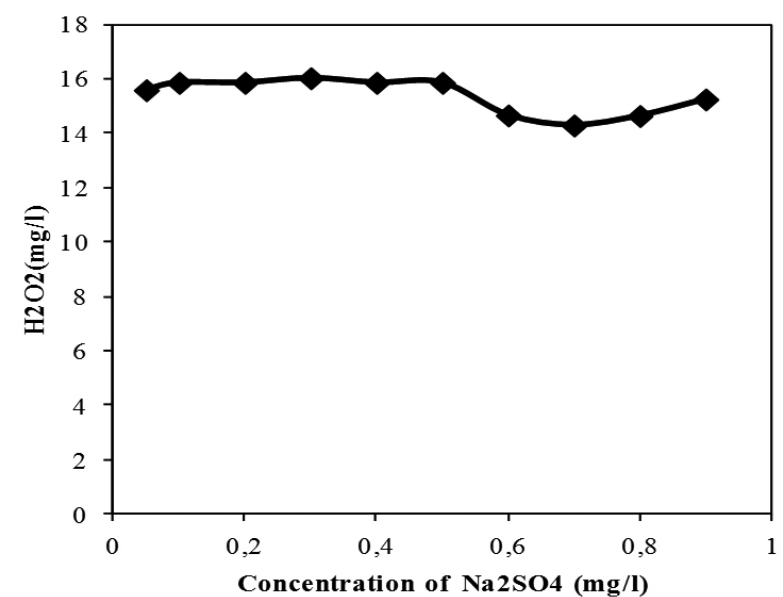
$\mathrm{H}_{2} \mathrm{O}_{2}$

Figure 7. Effect of the concentration of $\mathrm{Na}_{2} \mathrm{SO}_{4}$ in electro-generation of

Experimental conditions: time of aeration $1 \mathrm{H}$ time of electrolysis $120 \mathrm{~min}$ and $\mathrm{E}=-500 \mathrm{mV} / \mathrm{SCE}$.

Electrochemical characterization of N, $\mathbf{N}$ Methylenebismorpholine:

The electrochemical behavior of the biocide N, N Methylenebismorpholine was analyzed using cathodic and anodic potentiodynamic polarizations. A solution of $\mathrm{Na}_{2} \mathrm{SO}_{4}(0.05 \mathrm{M})(\mathrm{p} \quad \mathrm{H}$ 3) added with $1 \mathrm{ml}$ of $\mathrm{N}$, N-Methylenebismorpholine was experimented on graphite electrode. The $\mathrm{pH}$ was systematically controlled during all experiment.

Cathodic polarization:

The graphite electrode was cathodically polarized in the potential range of 0 to $-1300 \mathrm{mV} / \mathrm{SCE}$ with a scan rate of $2 \mathrm{mV} / \mathrm{s}$.

The result in figure ( $8 b$ ) shows the effect of biocide on the electrochemical behavior of the system. The potentials of oxygen and hydrogen reduction moved to larger negative values and the limiting current of oxygen becomes higher.

The addition of biocide increases the $\mathrm{pH}$ from 3 to 7 moving the potentials of hydrogen evolution to more negative values in accordance with thermodynamics data.

Anodic polarization:

Figure 9, shows the result of anodic polarization of graphite at the potential range of 0 to $1400 \mathrm{mV} / \mathrm{SCE}$. The curve (9a), without Biocide, shows one anodic limiting current relative to the oxidation of water to hydrogen peroxide in the potential range of: $\mathrm{E}=150$ to $700 \mathrm{mV} / \mathrm{SCE}$ :

$$
\mathrm{H}_{2} \mathrm{O} \rightarrow \mathrm{H}_{2} \mathrm{O}_{2}+2 \mathrm{H}^{+}+2 \mathrm{e}^{-\quad 7}
$$

The addition $1 \mathrm{~mL}$ of Biocide, exhibits two limiting currents in the potential range of $70 \mathrm{mV} / \mathrm{SCE}$ to $400 \mathrm{mV} / \mathrm{SCE}$ for the first one and $400 \mathrm{mV} /$ $\mathrm{SCE}$ to $600 \mathrm{mV} / \mathrm{SCE}$ for the second. Oxygen gas evolution occurs for anodic potential more positively for the solution containing biocide.

The second limiting current corresponds to an oxidation process controlled by a mass transfer.

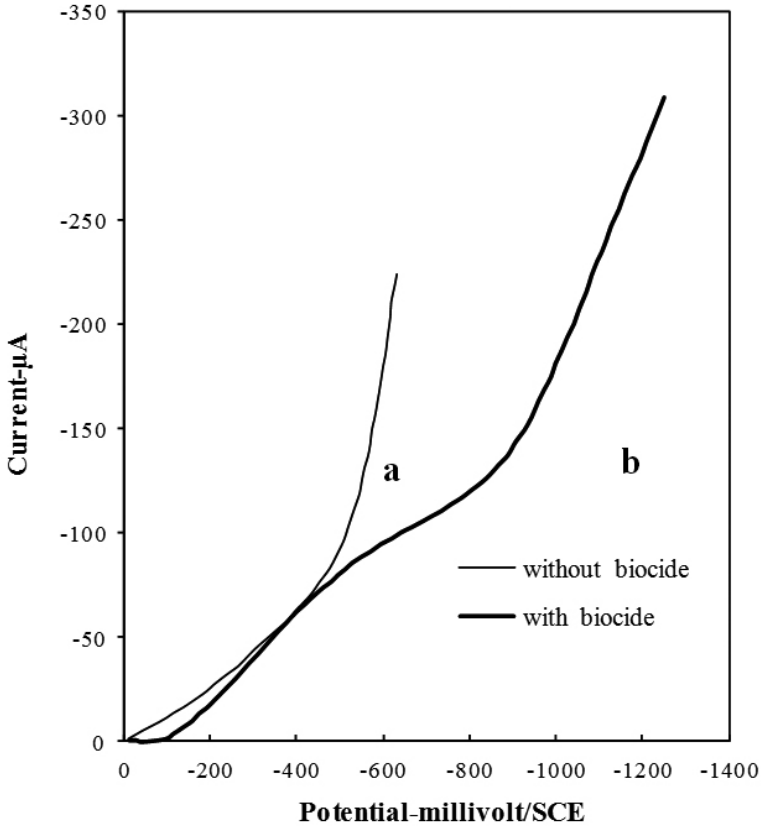

Figure 8. Influence of biocide on the cathodic polarization $\mathrm{Na}_{2} \mathrm{SO}_{4} 0.05 \mathrm{M}, \mathrm{H}_{2} \mathrm{SO}_{4} \mathrm{pH}=3, \mathrm{~S}=2 \mathrm{mV} / \mathrm{s}, \mathrm{N}_{\mathrm{r}}=4000 \mathrm{rds} / \mathrm{min}$ a: without biocide, $\mathbf{b}$ : with biocide pure $1 \mathrm{ml}$.

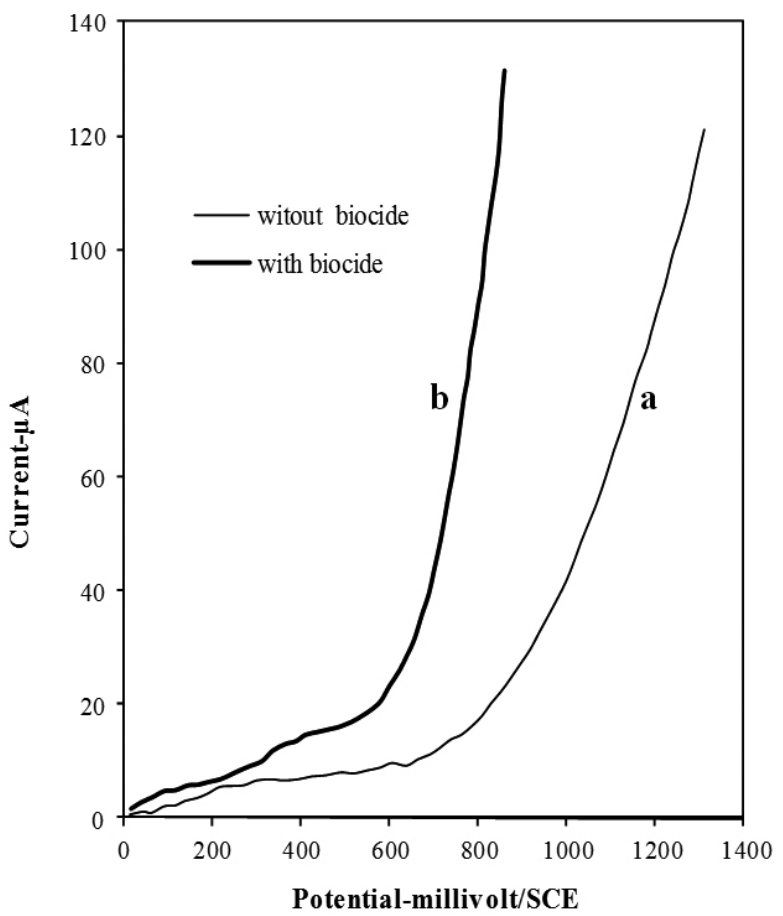

Figure 9. Influence of biocide on the anodic polarization $\mathrm{Na}_{2} \mathrm{SO}_{4} 0.05 \mathrm{M}, \mathrm{H}_{2} \mathrm{SO}_{4} \mathrm{pH}=3, \mathrm{~S}=2 \mathrm{mV} / \mathrm{s}, \mathrm{N}_{\mathrm{r}}=4000 \mathrm{rds} / \mathrm{min}$ a: without biocide, $\mathbf{b}$ : with biocide pure $1 \mathrm{ml}$.

The electrochemical behavior of N,N-Methylenebismorpholine depends on the applied potential and its polarity. In the cathodic regions, the potentials of reduction of oxygen and hydrogen moved to the higher negative values. This result can be attributed to the alkaline nature of N,N-Methylenebismorpholine.

The neutralizing effect of biocide must be considered for the application of electro- Fenton process and the $\mathrm{pH}$ was systematically controlled.

In the anodic regions, $\mathrm{N}, \mathrm{N}-$ Methylenebismorpholine oxidizes in a potential 
range of: $\mathrm{E}=400 \mathrm{mV} / \mathrm{SCE}$ to $\mathrm{E}=600 \mathrm{mV} / \mathrm{SCE}$ with a controlled diffusion kinetics.

This result appears interesting because it represents an opportunity for a direct incineration of the biocide.

Optimization of incineration parameters:

Indirect incineration of $\mathrm{N}, \mathrm{N}-$ Methylenebismorpholine was performed using an galvanostatic experimental device .

A DC generator LEYBOLDS $15 \mathrm{~V} / 20 \mathrm{~A}$ was used as a current source, industrial graphite and platinum were used as cathode and anode respectively. The digital ammeter and millivotmeter were used for current and potential measurements.

A solution of $0.05 \mathrm{M} \mathrm{Na}_{2} \mathrm{SO}_{4}$, air saturated $(7 \mathrm{mg} / \mathrm{l})$ at $\mathrm{pH} 3$ were used for all experiments.

The solution was magnetically stirred and air was bubbled during all the experiment. Ferrous sulfate was added as Fenton catalyst, 5 minutes before starting the electrolysis. $\mathrm{pH}$ was adjusted in the range of 2.5 to 3 by the adding of sulfuric acid.

The performance of incineration was controlled by COD analysis every hour. Effect of applied current and ratio $\mathrm{COD} / \mathrm{Fe}^{++}$were experimented.

\section{The effect of ferrous Sulfate:}

A solution of $200 \mathrm{ml}$ of $0.05 \mathrm{M}$ sodium sulfate containing pure biocide (COD: $1000 \mathrm{mg} / \mathrm{l})$ was first galvanostatically $(\mathrm{I}=30 \mathrm{~mA}$ ) electrolyzed during six hours without addition of ferrous ions, the residual COD was analyzed every hour. Figure (10a) shows different changes on COD concentration.

The addition of $12 \mathrm{mg} / \mathrm{l}$ of ferrous ions corresponding to an approximate ratio of $\left[\mathrm{H}_{2} \mathrm{O}_{2}\right] /[$ ironII $]=2^{34}$ shows a decrease in residual COD Figure (10b); a residual concentration of $580 \mathrm{mg} / \mathrm{l}$ was unregistered after $5 \mathrm{~h}$ of electrolysis representing to an efficiency of $42 \%$.

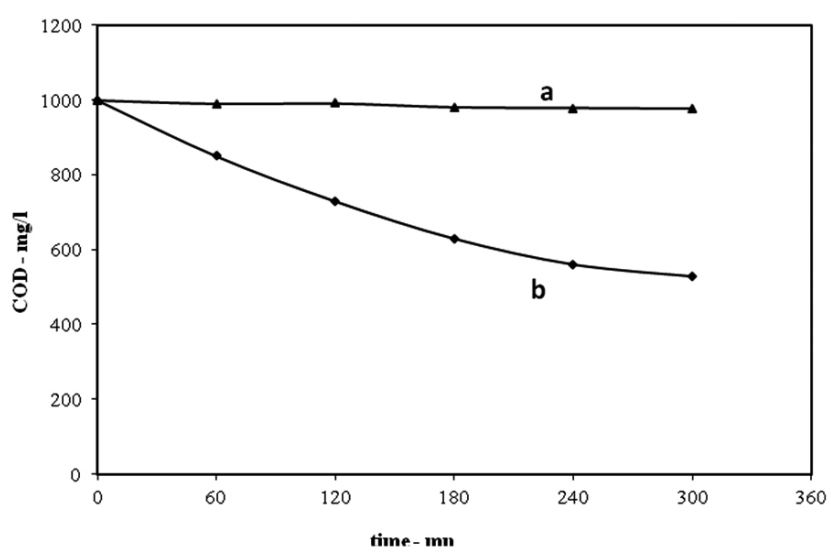

Figure 10. Abatement of COD as a function of time.

a: not catalyst b: with a catalyst, $\left[\mathrm{Fe}^{2+}\right]=12 \mathrm{mg} / 1$. I $=30 \mathrm{~mA}$.

\section{Applied current effect}

Applied current of 12,30.50,75 and 100mA were used in similar conditions of previous experiment; figure 11 shows time evolution of the residual COD.

The kinetics appears more rapid during the first two hours then the decrease of residual COD becomes lower.

The residual values of COD for six hours of electrolysis and for different applied currents are shown in Figure (12).

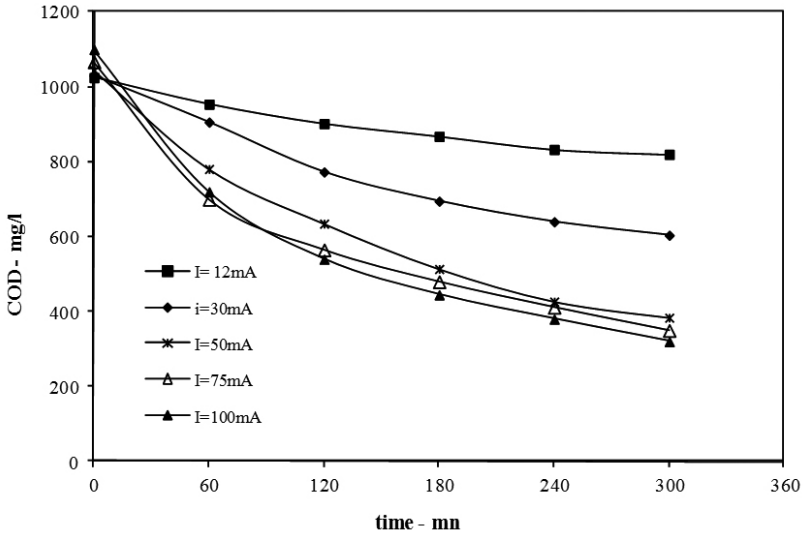

Figure 11. Effect of applied current on the incineration of biocide. $0,05 \mathrm{M} \mathrm{Na}_{2} \mathrm{SO}_{4} \mathrm{pH}=3, \mathrm{CODi}=1000 \mathrm{mg} / \mathrm{l} \pm 100,\left[\mathrm{Fe}^{2+}\right]=12 \mathrm{mg} / \mathrm{l}$, $\mathrm{C}_{\mathrm{O} 2}=7 \mathrm{mg} / \mathrm{l}$.

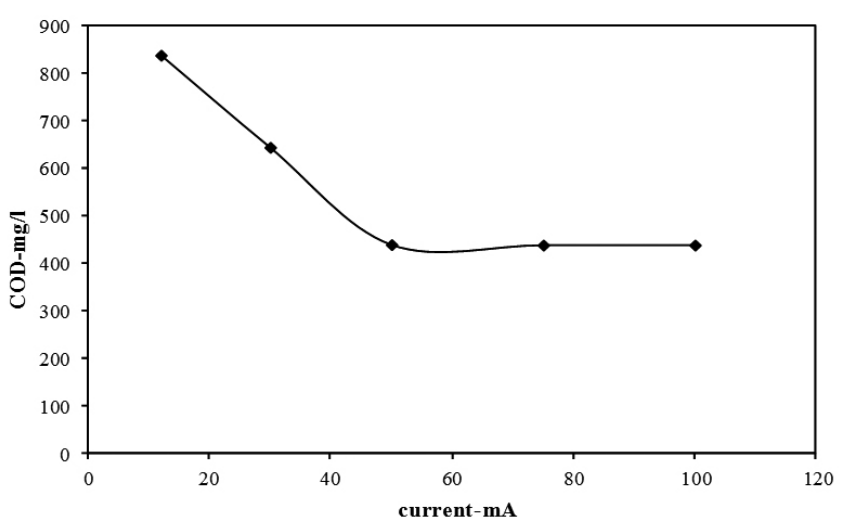

Figure 12. Variation of residual concentration of COD as a function of current

The result shows two parts of different applied currents. For the current less than $-50 \mathrm{~mA}\left(-1.4 \mathrm{~mA} / \mathrm{cm}^{2}\right)$, the rate of incineration of the biocide increase with the applied current, for the current higher than $50 \mathrm{~mA}$ the rate of incineration stabilises and becomes independent.

The current density of $-1.4 \mathrm{~mA} / \mathrm{cm}^{2}$ for N,N Methylenebismorpholine incineration represents an optimum, the potential of the cathode was unregistered each $30 \mathrm{mn}$ and showed a variation in the values range of : - 480 $\mathrm{mV} / \mathrm{SCE}$ at starting of electrolysis to $-620 \mathrm{mV} / \mathrm{SCE}$ at the end of electrolysis.

\section{Ratio COD/ (FeII) effect}

The effect ratio of $\mathrm{COD} /(\mathrm{FeII})$ on efficiency of the incineration was experimented for two hours of galvanostatic electrolysis $(50 \mathrm{~mA})$.

A solution of $\mathrm{Na}_{2} \mathrm{SO}_{4} 0.05 \mathrm{M}(\mathrm{pH} 3)$ saturated with air and magnetically stirred was used in all experiments.

$\mathrm{N}, \mathrm{N}$ Methylenebismorpholine was added in the saturated air sulphate solution and the equivalent of COD was systematically analyzed.

Concentrations of 12 to $224 \mathrm{mg} / 1$ of $\mathrm{Fe}^{2+}$ were experimented, figure (13) shown the results.

Figure (13), shows a maximum efficiency for a COD / Fe II ratio of 20 to 30 , then a decrease in efficiency with an increasing concentration of catalyst $\mathrm{Fe}^{2+}$.

The decrease in the rate of degradation of biocide for a higher concentration of $\mathrm{Fe}^{2+}$ is due to the reduction in hydroxyl radicals.

$$
\mathrm{Fe}^{2+}+\mathrm{OH}^{-} \square \mathrm{Fe}^{3+}+\mathrm{OH}^{-} \quad \mathrm{k}=3.2 \square 10^{8} \mathrm{M}^{-1} \mathrm{~s}^{-1} 35
$$




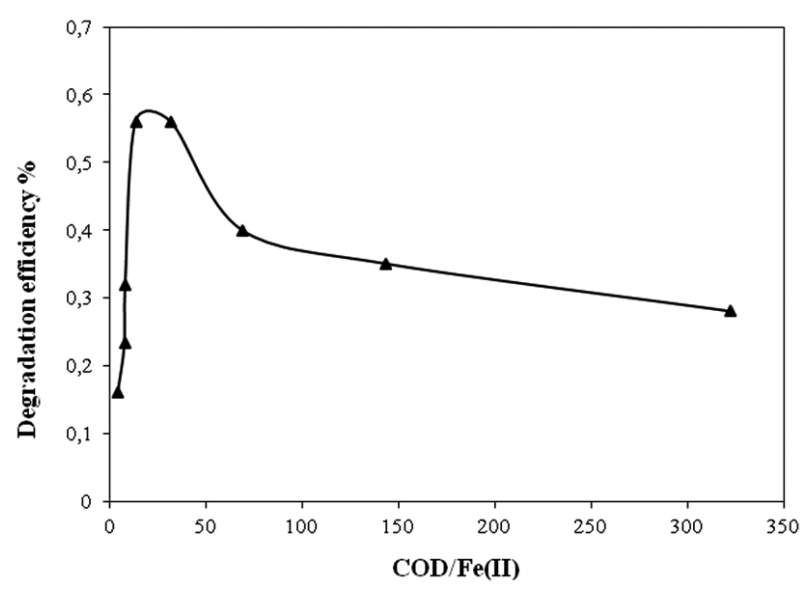

Figure 13. Effect of the ratio $\mathrm{COD} / \mathrm{Fe}^{++}$on efficiency of incineration.

The optimal concentration of ferrous ions for the degradation ofN,NMethylenebismorpholine is in the range of 30 to $50 \mathrm{mg} / \mathrm{l}$ for an applied current of $50 \mathrm{~mA}$ and a level of COD to mineralize of 900 to $1000 \mathrm{mg} / \mathrm{l}$.

\section{Incineration of N, N Methylenebismorpholine:}

This experiment represents the application of the optimized parameters of indirect incineration of N,N Methylenebismorpholine contained in an aqueous acidified sulphate solution saturated with air .

The solution was first aerated by air insufflations for two hours and then electrolyzed during 1 hour to produce and accumulate hydrogen peroxide.

The solution was magnetically stirred and air was introduced with a rate of 1 litre per minute during all experiments.

The biocide and Fe II were then introduced after the electro generation of hydrogen peroxide. At each hour, we analyzed the residual COD. This result is represented in Figure (14).

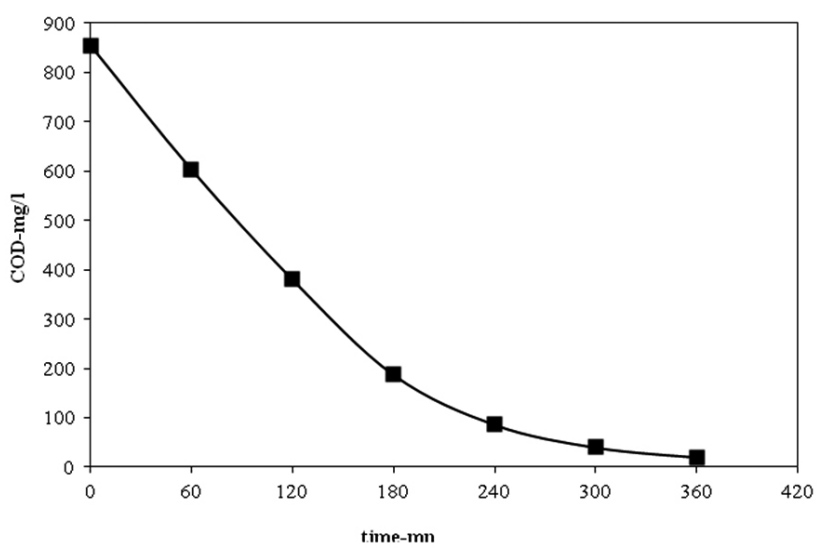

Figure14. Evolution of residual COD with time of electrolysis $\mathrm{Na}_{2} \mathrm{SO}_{4}(0,05 \mathrm{M}), \mathrm{p} \mathrm{H} 3, \mathrm{I}=50 \mathrm{~mA}, \quad \mathrm{Fe} \mathrm{II}=30 \mathrm{mg} / 1, \mathrm{C}_{\mathrm{O} 2}: 7 \mathrm{mg} / 1$ Initial COD: $880 \mathrm{mg} / \mathrm{l}$

The Figure 14 shows a complete mineralization of the biocide after six hours of electrolysis. The residual COD is $22 \mathrm{mg} / \mathrm{l}$ and the efficiency is $97 \%$.

\section{CONCLUSION}

Cathodic incineration catalyzed by ferrous /ferric redox ion pair (ElectroFenton) of the N,N-Methylenebismorpholine showed a very good efficiency, more than $97 \%$ of the associated COD was oxidized after five hours of electrolysis.

Industrial graphite, largely used in electrical and electrochemical industries was used as cathode in this study; it exhibits a good electrochemical behavior with high hydrogen overpotential and a good availability.
A potential range of $-500 \mathrm{mV} / \mathrm{SCE}$ to $-550 \mathrm{mV} / \mathrm{SCE}$ are optimal for the electrogeneration of hydrogen peroxide and the incineration of $\mathrm{N}, \mathrm{N}$ Methylenebismorpholinein the Electro Fenton process.

A COD $/ \mathrm{Fe}^{++}$ratio of approximately 30 represented the best ratio in this study, $97 \%$ of COD was incinerated after two hours of saturated aeration and five hours of electrolysis.

The electro Fenton process exhibits, large possibilities for incineration or pre-incineration of refractory substances to biological treatments.

The N,N-Methylenebismorpholine presents an anodic electroactivity and offers other electrochemical possibilities for the treatment of aqueous waste containing this substance.

\section{ACKNOWLEDGMENTS}

The author gratefully acknowledges Dr. Zerouali Djilali for his helpful discussion.

\section{REFERENCES}

1. W.R Chen, C.M Sharpless, et al, Environ. Sci. Technol.,40, 2734-2739, (2006)

2. M.O Buffle, G.V Gunten, Environ. Sci. Technol.,40, 3057-3063,(2006)

3. J Riquelme-Valdes, E Ramirez, et al, J. Chil. Chem. Soc, 53, 4, (2008).

4. P.Ghosh, A.N Samanta,et al. Desalination., 5,DES-10187,(2010)

5. M.Ogura, I.Astuti,et al, Ind. Eng.Chem. Res., 43, 1890-1893,(2004)

6. J.A Zazo, J.A Casas, et al, Environ. Sci.Technol., 39, 9295-9302,(2005).

7. M Pourbaix., Atlas d'équilibres électrochimiques. Edition : GauthierVillars Paris, 1963

8. M.A Oturan, J. Pinson,J. Phys. Chem.,99(38), 13948-13954,(1995)

9. M.S.El-Deab, T.Okajima, et al, Journal of the Electrochemical Society,150 (7) A851-A857, (2003)

10. A.A.Gallegos, D Pletcher,. Electrochimca. Acta, ,44(14), 2483-2492, (1999)

11. Y.B Xie,. X.Z. Li, Mater. Chem. Phys., , 95,(1), 39-50, (2006)

12. A.Wang, J. Qu, et al, Dyes Pigments, Journal of Zhejiang University Science A,65(3), 227-233, (2005)

13. M.A Oturan. ,J Appl Electrochem, ,30, 475-782,(2000)

14. K Hanna,S. Chiron, et al, Water Research, , 39(12), 2763-2773 (2005)

15. J.J Aaron, M.A Oturan, Environmental applications, Turk. J. Chem., ,25(4), 509-520, (2001)

16. E. Brillas, E. Mur, et al, Appl. Catal. B-Environ, 16(1), 31-42,(1998)

17. B Boye, M.M. Dieng, et al , Environ Sci. Technol, 36(13), 3030-3035. (2002)

18. E.Brillas, B. Boye, et al, Electrochimca. Acta, 49(25), 4487-4496,(2004)

19. Y.H Huang, S. Chou, et al, Water Sci.Technol., 39 145-149,(1999)

20. C Flox, S. Ammar, et al,Appl. Catal. B: Environ., 67, 93-104,(2006)

21. A Morão, A.Lopes, et al, Electrochemica Acta.,49, 1587-1595,(2004)

22. Eisenberg G.M. Industrial and Engineering chemistry, ,15(5), 1943,pp.327-328

23. Z.Qiang., J.H Chang ,et al.Water Research, ,36, 85-94, (2002)

24. M.A Oturan, J. Pinson. New J.Chem.,16, 705-710,(1992).

25. C.H Chu, The electrochemical oxidation of recalcitrant organic compounds. Ph.D. dissertation, University of Delaware, Newark, DE, (1995).

26. Y.H Hsiao, K Nobe,. J. Appl. Electrochem, ,23, 943-946,(1993)

27. T Tzedakis, A. Savall , M.J Clifton, J. Appl. Electrochem., ,19, 911921,(1989)

28. Y Sun, J.J Pignatello. Environ. Sci. Technol.,27, 304-310,(1993)

29. B.G Kwon, , D.S. Lee, et al,. Water Res., 33 (9) : 2110-2118,(1999)

30. M. Zhou, Yu, Q,et al, Purif. Technol.,57 (2) : 380-387,(2007)

31. W.P Ting, M.C.Lu, et al, J. Hazard. Mater.,161 (2-3) : 1484-1490,(2009)

32. E Brillas. B Boye, et al, Chemosphere, ,51,227-235,(2003)

33. I Sires, C.Arias, et al, J.Environ.Chem.,1,26-28,(2004)

34. E. Petrucci, A. Da Pozzo, P, et al, J. Appl. Electrochem, 35, 391-498, (2005)

35. M.C Edelhi, Contribution à l'étude de dégradation in situ des pesticides par procédés d'oxydation avancés faisant intervenir le fer. Application aux herbicides phénylurées. Doctorat de l'université de Marne-La-Vallée. Université de Marne-La-Vallée, 2004. 